\title{
The Effects of Infusion of Calcium and Magnesium Ions on the Cardiovascular System in Man
}

\author{
Kiyoo MoRI, M.D.
}

\section{SUMMARY}

The effects of $\mathrm{Ca}^{++}$and $\mathrm{Mg}^{++}$infusion on the cardiovascular system were studied in 96 normotensive subjects and 85 hypertensive patients. The results obtained were as follows:

(1) The effects of $\mathrm{Ca}^{++}$infusion on the systolic time intervals were characterized by the shortening of $\mathrm{QS}_{2} \mathrm{I}, \mathrm{PEPI}$, and ICT, and increase in ET/PEP. The responses of the systemic hemodynamics were elevation of mean blood pressure and increase in cardiac index and stroke index. The heart rate was not altered.

(2) These results support that $\mathrm{Ca}^{++}$has a positive inotropic action and increases the left ventricular performance.

(3) The effects of $\mathrm{Mg}^{++}$infusion on the systolic time intervals were characterized by the prolongation of $\mathrm{QS}_{2} \mathrm{I}$, PEPI, and ICT. The responses of systemic hemodynamics were elevation of mean blood pressure and increase in heart rate. The ET/PEP and cardiac index tended to decrease, but these changes were not significant.

(4) From these results it is suggested that $\mathrm{Mg}^{++}$depresses myocardial contractility and has a positive chronotropic action.

(5) There were no significant differences in the systolic time intervals and hemodynamic responses to the infusion of $\mathrm{Ca}^{++}$and $\mathrm{Mg}^{++}$ between normotensives and hypertensives.

\section{Additional Indexing Words:}

Divalent cation Systolic time intervals Systemic hemodynamics Hypertension

$7 \mathrm{HE}$ influence of divalent cations on the heart and vascular smooth muscle has been studied by several investigators. ${ }^{1-4)}$ It is well known that excitation-contraction coupling in heart muscle cell depends upon an inward displacement of $\mathrm{Ca}^{++}$from the extracellular to the intracellular phase. ${ }^{51}$ Baston and Makay showed that the contracture tension of superfused ventricle of helix aspersa could be altered by varying the $\mathrm{Ca}^{++}$and $\mathrm{Mg}^{++}$concentrations of perfusion medium. ${ }^{6}$ ' The tension was decreased immediately after the level of $\mathrm{Ca}^{++}$was lowered while increased after the level of $\mathrm{Mg}^{++}$was lowered.

From the Second Department of Internal Medicine, Kanazawa University, Kanazawa, Japan. Present address and address for reprints: Kiyoo Mori, M.D., Department of Internal Medicine, Ishikawa Prefectural Central Hospital, 153 Minami-shinbomachi, Kanazawa 920, Japan.

Received for publication August 15, 1977. 
On the other hand, Hoffman and Suckling found that an excess and deficiency of magnesium had little effect on the action potential of papillary muscles of dog as far as calcium concentration was normal.")

From the standpoint of the significance of sarcoplasmic reticulum in the pathogenesis of hypertension, Aoki urgued that the $\mathrm{Ca}^{++}$binding of isolated sarcoplasmic reticulum was lower in the aorta of spontaneously hypertensive rat. ${ }^{8)}$ Another clinical study indicated that the exchangeable magnesium and serum magnesium levels were decreased in hypertensive man as compared with normotensive man.9

However, there are few available reports concerning the role of these divalent cations on the cardiac function and systemic hemodynamics. The purpose of the present study, thereforc, was to evaluate the effects of intravenous infusion of $\mathrm{Ca}^{++}$and $\mathrm{Mg}^{++}$on the cardiovascular system in man, and secondarily to compare the cardiovascular responses to intravenous infusion of $\mathrm{Ca}^{++}$and $\mathrm{Mg}^{++}$between normotensive controls and hypertensive patients.

\section{Máterials and Methods}

The normotensive subjects were volunteers who had no evidence of heart, lung, renal, blood, and metabolic diseases. The hypertensive patients were defined as subjects who had blood pressure persistently higher than $150 / 90 \mathrm{mmHg}$ without secondary hypertension, heart failure, histories of renal disease, myocardial infarction, and cerebrovascular accident. At least 10 days prior to the study the drugs were discontinued, and these studies were performed without premedication in a quiet laboratory. The left ventricular systolic time intervals were obtained by noninvasive technique using carotid artery tracing and the hemodynamic studies were done by dye-dilution method before and immediately after intravenous infusion of $0.2 \mathrm{mEq} / \mathrm{Kg}$ of Ca ${ }^{++}$(Ca-l-Asparate) over $5 \mathrm{~min}$ or $0.1 \mathrm{mEq} / \mathrm{Kg}$ of $\mathrm{Mg}^{++}(\mathrm{Mg}-\mathrm{l}-$ Asparate) over $5 \mathrm{~min}$. With respect to the study of $\mathrm{Ca}^{++}$, the systolic time intervals were measured in 21 normotensive subjects (mean age 42; range 26-68 years) and 17 hypertensive patients (mean age 47 ; range $20-70$ years), and the hemodynamic observations were made in 26 normotensive subjects (mean age 42; range 16-78 years) and 25 hypertensive patients (mean age 47 ; range $23-69$ years). With respect to the study of $\mathrm{Mg}^{++}$, the systolic time intervals were measured in 22 normotensive subjects (mean age 41; 16-68 years) and 21 hypertensive patients (mean age 39; 16-62 years), and the hemodynamic observations were made in 26 normotensive subjects (mean age 46; 24-74 years) and 22 hypertensive patients (mean age 49; $24-68$ years).

For the carotid pulse recording a Fukuda TY 302 transducer was used. Simultaneous EGG (Lead II), phonocardiogram and carotid pulse tracing were recorded in supine position at a paper speed of $100 \mathrm{~mm} / \mathrm{sec}$ on a Siemens-Elema Mingograph No. 828 channel recorder with the method of Weissler, Harris, and Schoenfeld. $\left.{ }^{10}\right)$ The total electromechanical systole $\left(\mathrm{QS}_{2}\right)$, left ventricular ejection time (ET), preejection period (PEP), isovolumic contraction time (ICT), and ratio of ejection 
time to the preejection period (ET/PEP) were measured, using the averages of 5 tcchnically adequate consecutive beats, and were corrected for heart rate to give the respective indexes $\mathrm{QS}_{2} \mathrm{I}, \mathrm{ETI}$, and PEPI. Cardiac output was determined by dye-dilution method using Water's D-400 earpiece densitometer. A 19-gauge 300 $\mathrm{mm}$ polyethylene catheter was inserted percutaneously into right antecubital vein. Following the injection of indocyanine green $(10 \mathrm{mg})$ with flash of $10 \mathrm{ml}$ of saline into central vcin, dilution curve were inscribed on a National pen recorder VP 2654. About $3 \mathrm{~min}$ after the injection, blood samples for calibration were withdrawn from another antecubital vein. The area under each dye curve was measured by planimetry and the cardiac output was calculated by the StewartHamiltion principle. ${ }^{11}$ ) Hemodynamic parameters were calculated according to the previous report. ${ }^{121}$

\section{Results}

Following the infusion of $\mathrm{Ca}^{++}$, plasma $\mathrm{Ca}^{++}$concentration was elevated by an average of $0.59 \pm 0.28$ (S.D.) $\mathrm{mEq} / \mathrm{L}$ and following the infusion of $\mathrm{Mg}^{++}$, plasma $\mathrm{Mg}^{++}$concentration was elevated by an average of $0.69 \pm 0.38$ (S.D.) $\mathrm{mEq} / \mathrm{L}$. The infusion of $\mathrm{Ca}^{++}$and $\mathrm{Mg}^{++}$did not affect other plasma electrolyte concentrations.

I. Comparison of the control values in systolic time intervals and hemodynamics between normotensives and hypertensives (Tables I-IV)

There were no differences in systolic time intervals, heart rate, cardiac index, and stroke index between normotensives and hypertensives. The hyper-

Table I. Effects of $\mathrm{Ca}^{++}$Infusion on Systolic Time Intervals

\begin{tabular}{|c|c|c|c|c|c|c|}
\hline \multicolumn{2}{|c|}{$\mathrm{Ca}^{++}$infusion } & Control \pm S.D. & ${ }_{\text {(vs. } \mathrm{NT} \text { ) }}$ & $\begin{array}{c}\text { After } \\
\text { infusion } \pm \text { S.D. }\end{array}$ & Change \pm S.D. & $\underset{\text { control) }}{p(v s .}$ \\
\hline \multirow{2}{*}{$\mathrm{QS}_{2} \mathrm{I} \mathrm{msec}$} & NT & $525 \pm 10.7$ & & $518 \pm 13.9$ & $-8 \pm 7.7$ & 0.001 \\
\hline & $\mathrm{HT}$ & $520 \pm 15.7$ & ns & $511 \pm 17.8$ & $-8 \pm 9.6$ & 0.005 \\
\hline \multirow{2}{*}{ ETI msec } & NT & $401 \pm 25.8$ & & $398 \pm 26.3$ & $-2 \pm 5.5$ & 0.10 \\
\hline & $\mathrm{HT}$ & $391 \pm 17.1$ & ns & $391 \pm 18.0$ & $-0 \pm 5.7$ & ns \\
\hline \multirow{2}{*}{ PEPI msec } & NT & $121 \pm 13.2$ & & $115 \pm 14.0$ & $-6 \pm 5.7$ & 0.001 \\
\hline & HT & $126 \pm 13.0$ & ns & $119 \pm 13.9$ & $-7 \pm 7.6$ & 0.005 \\
\hline \multirow{2}{*}{ ICT msec } & NT & $43 \pm 13.8$ & & $41 \pm 13.8$ & $-3 \pm 6.5$ & 0.05 \\
\hline & $\mathrm{HT}$ & $49 \pm 13.6$ & ns & $44 \pm 18.0$ & $-5 \pm 9.0$ & 0.05 \\
\hline \multirow{2}{*}{ ET/PEP } & NT & $3.117 \pm 0.521$ & & $3.330 \pm 0.656$ & $+0.214 \pm 0.275$ & 0.005 \\
\hline & $\mathrm{HT}$ & $2.825 \pm 0.483$ & ns & $3.126 \pm 0.711$ & $+0.229 \pm 0.278$ & 0.005 \\
\hline
\end{tabular}

Each value represents the mean \pm 1 S.D.

Twenty-one normotensives and 17 hypertensives were studied.

Abbreviations : $\mathrm{NT}=$ normotensive subject; $\mathrm{HT}=$ hypertensive patient; ns $=$ not significant. 
Table II. Effects of $\mathrm{Ca}^{++}$Infusion on Systemic Hemodynamics

\begin{tabular}{|c|c|c|c|c|c|c|}
\hline \multicolumn{2}{|c|}{$\mathrm{Ca}^{++}$infusion } & Control \pm S.D. & \multirow[t]{2}{*}{${ }_{\text {(vs. }}^{p}$ NT) } & $\begin{array}{c}\text { After } \\
\text { infusion } \pm \text { S.D. }\end{array}$ & Change $\pm S . D$ & \multirow{3}{*}{$\begin{array}{c}\text { p (vs. } \\
\text { control) } \\
\text { ns } \\
\text { ns }\end{array}$} \\
\hline & NT & $67 \pm 8.6$ & & $68 \pm 11.6$ & $+2 \pm \quad 8.2$ & \\
\hline $\mathrm{s} / \mathrm{min}$ & HT & $68 \pm 12.6$ & $\mathrm{~ns}$ & $69 \pm 14.0$ & $+1 \pm \quad 6.2$ & \\
\hline \multirow{2}{*}{$\begin{array}{l}\text { MBP } \\
\text { mmHg }\end{array}$} & NT & $87 \pm 9.1$ & & $93 \pm 11.6$ & $+6 \pm 7.6$ & 0.001 \\
\hline & $\mathrm{HT}$ & $113 \pm 9.8$ & 0.001 & $122 \pm 12.7$ & $+9 \pm 9.0$ & 0.001 \\
\hline \multirow{2}{*}{$\begin{array}{l}\mathrm{CI} \\
\mathrm{L} / \mathrm{min} / \mathrm{M}^{2}\end{array}$} & NT & $3.9 \pm 1.01$ & & $4.7 \pm 1.40$ & $+0.8 \pm 0.24$ & 0.001 \\
\hline & HT & $4.0 \pm 1.23$ & ns & $4.6 \pm 1.31$ & $+0.6 \pm 0.62$ & 0.005 \\
\hline \multirow{2}{*}{$\begin{array}{l}\mathrm{SI} \\
\mathrm{ml} / \text { beat } / \mathrm{M}^{2}\end{array}$} & NT & $60 \pm 16.4$ & & $70 \pm 20.7$ & $+10 \pm 12.9$ & 0.001 \\
\hline & $\mathrm{HT}$ & $59 \pm 15.0$ & ns & $68 \pm 18.1$ & $+8 \pm 9.4$ & 0.001 \\
\hline \multirow{2}{*}{$\begin{array}{l}\text { TPRI } \\
\text { dyn } \cdot \text { sec. } \\
\mathrm{cm}^{-5} \cdot \mathrm{M}^{2}\end{array}$} & NT & $1876 \pm 479.1$ & & $1702 \pm 501.4$ & $-173 \pm 301.9$ & 0.01 \\
\hline & $\mathrm{HT}$ & $2395 \pm 693.1$ & 0.01 & $2277 \pm 714.6$ & $-139 \pm 341.6$ & $\mathrm{~ns}$ \\
\hline \multirow{2}{*}{$\begin{array}{l}\mathrm{LVWI} \\
\mathrm{Kg} \cdot \mathrm{M} / \mathrm{M}^{2}\end{array}$} & NT & $4.69 \pm 1.31$ & & $5.97 \pm 1.69$ & $+1.28 \pm 1.02$ & 0.001 \\
\hline & HT & $6.10 \pm 1.86$ & 0.01 & $7.83 \pm 1.93$ & $+1.29 \pm 1.11$ & 0.005 \\
\hline
\end{tabular}

Each value represents the mean \pm 1 S.D.

Twenty-seven normotensives and 25 hypertensives were studied.

Abbreviations: See Table I. $\mathrm{HR}=$ heart rate; $\mathrm{MBP}=$ mean blood pressure; $\mathrm{CI}=$ cardiac index ; SI =stroke index; TPRI = total peripheral resistance index; LVWI = left ventricular work index.

Table III. Effects of $\mathrm{Mg}^{++}$Infusion on Systolic Time Intervals

\begin{tabular}{|c|c|c|c|c|c|c|}
\hline \multicolumn{2}{|c|}{$\mathrm{Mg}^{++}$infusion } & Control $\pm S . D$ & (vs, ${ }^{p}$ NT) & $\begin{array}{c}\text { After } \\
\text { infusion } \pm \text { S.D. }\end{array}$ & Change \pm S.D. & $\begin{array}{c}\mathrm{p} \text { (vs. } \\
\text { control) }\end{array}$ \\
\hline \multirow{2}{*}{$\mathrm{QS}_{2} \mathrm{I}$ msec } & NT & $525 \pm 21.8$ & & $532 \pm 21.5$ & $+7 \pm 11.0$ & 0.05 \\
\hline & $\mathrm{HT}$ & $523 \pm 21.2$ & ns & $529 \pm 22.8$ & $+6 \pm 11.1$ & 0.05 \\
\hline \multirow{2}{*}{ ETI msec } & NT & $402 \pm 18.8$ & & $406 \pm 12.5$ & $+4 \pm 9.2$ & 0.1 \\
\hline & $\mathrm{HT}$ & $390 \pm 18.3$ & ns & $392 \pm 17.3$ & $+3 \pm 9.0$ & $\mathrm{~ns}$ \\
\hline \multirow{2}{*}{ PEPI msec } & NT & $123 \pm 12.1$ & & $126 \pm 12.8$ & $+3 \pm 5.0$ & 0.01 \\
\hline & HT & $134 \pm 22.8$ & ns & $137 \pm 22.3$ & $+4 \pm 5.9$ & 0.01 \\
\hline \multirow{2}{*}{ ICT msec } & NT & $40 \pm 14.1$ & & $43 \pm 13.5$ & $+3 \pm 4.7$ & 0.05 \\
\hline & HT & $46 \pm 13.6$ & ns & $51 \pm 15.6$ & $+6 \pm 7.8$ & 0.05 \\
\hline \multirow{2}{*}{ ET/PEP } & NT & $3.079 \pm 0.455$ & & $3.019 \pm 0.470$ & $-0.061 \pm 0.196$ & ns \\
\hline & $\mathrm{HT}$ & $2.762 \pm 0.761$ & $\mathrm{~ns}$ & $2.570 \pm 0.629$ & $-0.129 \pm 0.361$ & ns \\
\hline
\end{tabular}

Each value represents the mean \pm 1 S.D.

Twenty-two normotensives and 21 hypertensives were studied.

Abbreviations: See Table I. 
Table IV. Effects of $\mathrm{Mg}^{++}$Infusion on the Systemic Hemodynamics

\begin{tabular}{|c|c|c|c|c|c|c|}
\hline \multicolumn{2}{|c|}{$\mathbf{M g}^{++}$infusion } & Control \pm S.D. & \multirow[t]{2}{*}{$\begin{array}{c}\mathrm{P} \\
\text { (vs. NT) }\end{array}$} & $\begin{array}{c}\text { After } \\
\text { infusion } \pm S . D .\end{array}$ & Change $\pm S . D$ & \multirow{3}{*}{$\begin{array}{c}\begin{array}{c}\mathrm{p} \text { (vs. } \\
\text { control) }\end{array} \\
0.001 \\
0.01\end{array}$} \\
\hline & NT & $64 \pm 9.0$ & & $70 \pm 11.7$ & $+6 \pm 5.2$ & \\
\hline beats/min & $\mathrm{HT}$ & $68 \pm 9.1$ & ns & $72 \pm \quad 11.6$ & $+5 \pm 7.3$ & \\
\hline \multirow{2}{*}{$\begin{array}{l}\text { MBP } \\
\mathrm{mmHg}\end{array}$} & NT & $87 \pm \quad 9.4$ & & $92 \pm 13.4$ & $+5 \pm 8.8$ & 0.05 \\
\hline & $\mathrm{HT}$ & $121 \pm 13.2$ & 0.001 & $125 \pm 15.0$ & $+4 \pm 6.3$ & 0.01 \\
\hline \multirow{2}{*}{$\begin{array}{l}\mathrm{CI} \\
\mathrm{L} / \mathrm{min} / \mathrm{M}^{2}\end{array}$} & $\mathrm{NT}$ & $4.0 \pm 1.33$ & & $3.9 \pm$ & $-0.0 \pm 1.01$ & ns \\
\hline & $\mathrm{HT}$ & $3.9 \pm 1.85$ & ns & $3.8 \pm 1.73$ & $-0.1 \pm 0.85$ & ns \\
\hline \multirow{2}{*}{$\begin{array}{l}\mathrm{SI} \\
\mathrm{ml} / \text { beat } / \mathrm{M}^{2}\end{array}$} & $\mathrm{NT}$ & $63 \pm 19.0$ & & $56 \pm 18.6$ & $-8 \pm 14.3$ & 0.05 \\
\hline & $\mathrm{HT}$ & $58 \pm 25.6$ & ns & $53 \pm 20.9$ & $-6 \pm 12.6$ & 0.1 \\
\hline \multirow{2}{*}{$\begin{array}{l}\text { TPRI } \\
\text { dyn } \cdot \sec \\
\mathrm{cm}^{-5} \cdot \mathrm{M}^{2}\end{array}$} & NT & \multirow{2}{*}{$\begin{array}{l}1878 \pm 660.4 \\
2831 \pm 1123.1\end{array}$} & \multirow[b]{2}{*}{0.01} & \multirow{2}{*}{$\begin{array}{l}2071 \pm 878.3 \\
3040 \pm 1246.2\end{array}$} & \multirow{2}{*}{$\begin{array}{l}+193 \pm 588.2 \\
+253 \pm 631.7\end{array}$} & ns \\
\hline & $\mathrm{HT}$ & & & & & 0.1 \\
\hline \multirow{2}{*}{$\begin{array}{l}\mathrm{LVWI} \\
\mathrm{Kg} \cdot \mathrm{M} / \mathrm{M}^{2}\end{array}$} & NT & $4.80 \pm$ & & $5.00 \pm$ & $+0.25 \pm 1.39$ & ns \\
\hline & $\mathrm{HT}$ & $6.55 \pm$ & 0.01 & $6.42 \pm$ & $-0.13 \pm 1.37$ & ns \\
\hline
\end{tabular}

Each value represents the mean \pm 1 S.D.

Twenty-six normotensives and 22 hypertensives were studied.

Abbreviations: See Table II.

tensive patients in this study had compensated left ventricular performance, and systolic time intervals, cardiac index, and stroke index remained within normal limits.

\section{II. $\mathrm{Ca}^{++}$infusion}

1. Effects of $\mathrm{Ca}^{++}$infusion on systolic time intervals

There was significant shortening of $\mathrm{QS}_{2} \mathrm{I}, \mathrm{PEPI}$, and ICT in normotensives and hypertensives (Table I and Fig. 1). ET/PEP increased significantly, but ETI was not altered in both groups.

2). Effects of $\mathrm{Ca}^{++}$infusion on hemodynamics

The heart rate was not altered, but mean blood pressure, cardiac index, and stroke index increased significantly in normotensives and hypertensives (Table II and Fig. 2). The total peripheral resistance index decreased significantly in normotensives, but not in hypertensives.

However, there were no significant differences in systolic time intervals and hemodynamic parameters between normotensives and hypertensives.

\section{III. $\mathrm{Mg}^{++}$infusion}

1. Effects of $\mathrm{Mg}^{++}$infusion on systolic time intervals

There was significant prolongation of $\mathrm{QS}_{2} \mathrm{I}, \mathrm{PEPI}$, and ICT in normotensives and hypertensives (Table III and Fig. 1). ET/PEP tended to decrease and ETI tended to be prolonged in both groups, but these changes 


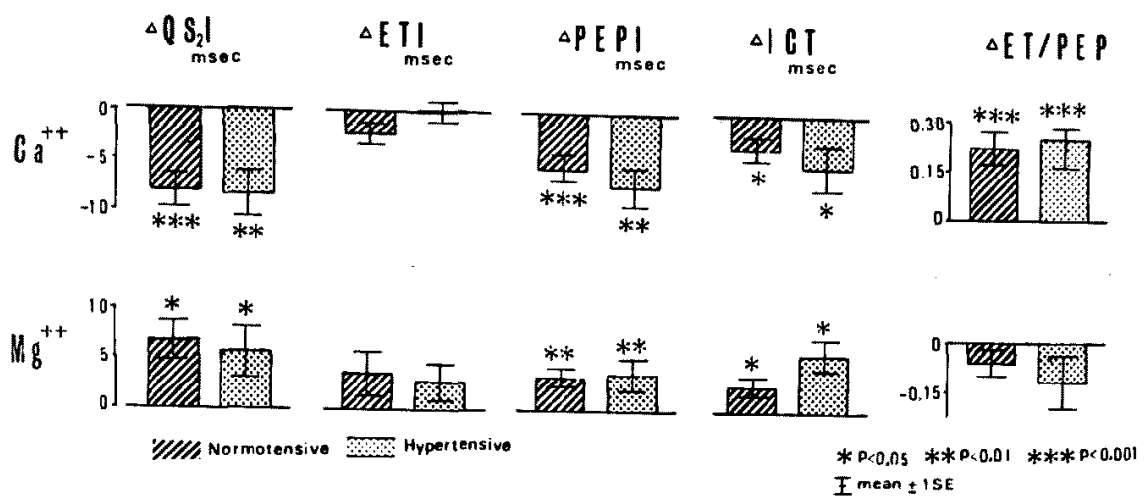

Fig. 1. Effects of $\mathrm{Ca}^{++}$and $\mathrm{Mg}^{++}$infusion on the systolic time intervals. Each parameter is expressed as changes from the control levels.

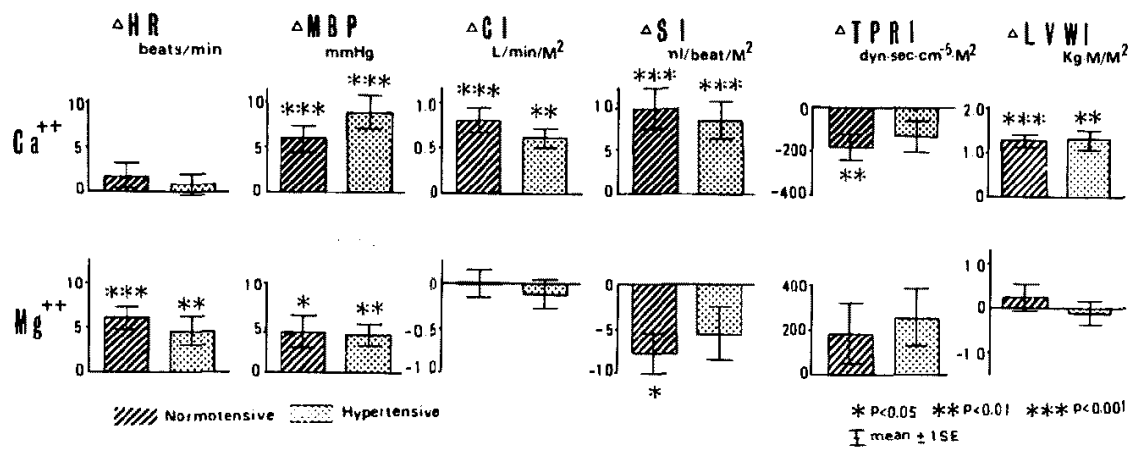

Fig. 2. Effects of $\mathrm{Ca}^{++}$and $\mathrm{Mg}^{++}$infusion on systemic hemodynamics. Each parameter is expressed as change from the control level.

were not significant.

2. Effects of $\mathrm{Mg}^{++}$infusion on the hemodynamics

The heart rate increased in normotensives and hypertensives (Table IV and Fig. 2). These changes were small, but statistically significant. The mean blood pressure rose significantly in normotensives and hypertensives. The cardiac index was not altered, and total peripheral resistance index tended to increase in both groups.

The response to $\mathrm{Mg}^{++}$infusion in hypertensives was similar to that in normotensives.

\section{Discussion}

It is known that $\mathrm{Ca}^{++}$plays an important role in the muscle contraction, but the precise mechamisms have not been elucidated. There is general agreement that the transition from the resting to the active state in heart muscle 
cells depends upon the increase in intracellular availability of $\mathrm{Ca}^{++}$, which comes from the internal stores of sarcoplasmic reticulum or extracellular

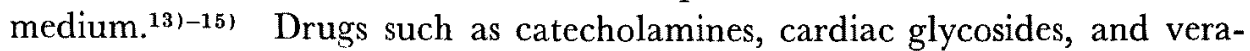
pamil alter the cardiac contractility by increasing or decreasing the amount of $\mathrm{Ca}^{++}$which becomes available for participation in the events associated with excitation-contraction coupling. ${ }^{16)-18)}$ Previous in vitro studies ${ }^{3), 61,19), 20)}$ showed that the contractile force of cardiac and smooth muscle was directly influenced by changes in external $\mathrm{Ca}^{++}$concentration. On the other hand, the effect of $\mathrm{Mg}^{++}$may be little as compared with the effect of $\mathrm{Ca}^{++}$, because there were no demonstrable effects of $\mathrm{Mg}^{++}$on the myogram of papillary muscle strips with omission of $\mathrm{Mg}^{++}$or a 10 -fold increase of $\mathrm{Mg}^{++}$concentration, ${ }^{21}$ and also a slight decrease in contractility of isolated guinea pig heart was found with an increase of $\mathrm{Mg}^{++}$from 0 to $4.5 \mathrm{mM} / \mathrm{L} .{ }^{22}$ )

In the present study, ETI, $\mathrm{QS}_{2} \mathrm{I}, \mathrm{PEPI}$, and ICT are decmed as representatives of cardiac contractility, ${ }^{23)-25}$ stroke volume, cardiac output, and ET/PEP as representatives of the pump function of heart, ${ }^{23), 26}$ ) heart rate as a representative of chronotropic effect, and total peripheral resistance as a representative of peripheral arterial condition. In this study, despite the small elevation of plasma $\mathrm{Ca}^{++}$and $\mathrm{Mg}^{++}$concentrations, many significant effects of these cations were observed. Although some workers ${ }^{8 / 9)}$ have stated calcium and magnesium might involve in the development of hypertension, the author could not find the difference in the response to infusion of $\mathrm{Ca}^{++}$and $\mathrm{Mg}^{++}$between normotensives and hypertensives.

Administration of $\mathrm{Ca}^{++}$was followed by prompt abbreviation in systolic time intervals. Weissler and Schoenfeld demonstrated that the changes in PEPI and ETI induced by digitalis correlated significantly with each of the hemodynamic responses (cardiac output, stroke volume). ${ }^{27}$ Increased ET/ PEP, shortened PEP and ICT, and increased cardiac index and stroke index produced by $\mathrm{Ca}^{++}$infusion were thought to be the result of increased performance of cardiac muscle.

Somjen and Baskerville demonstrated that administration of $\mathrm{Ca}^{++}$caused the increase of basal rhythm of heart in situ. ${ }^{1}$. Toda and West showed that the negative chronotropic response of isolated atrium of rabbit to vagal stimulation had increased exponentially with increase of concentration of $\mathrm{Ca}^{++}$ in the experimental solution. ${ }^{28)}$ In this study stroke index increased significantly after infusion of $\mathrm{Ca}^{++}$, under which the heart rate might be expected to decrease because of the inverted relationship between heart rate and stroke volume, ${ }^{10), 25)}$ and negative chronotropic effect of $\mathrm{Ca}^{++}$, but there was no change in the heart rate. It is suggested that the release of catecholamines might prevent the decrease in heart rate. ${ }^{\prime \prime}$ 
The infusion of $\mathrm{Mg}^{++}$showed the opposite effects to the infusion of $\mathrm{Ca}^{++}$ on systolic time intervals. The significant prolongation of PEPI and ICT appeared, ETI tended to be lengthened and ET/PEP tended to decrease. The systolic time intervals are influenced by multiple factors, such as ventricular volume, preload, afterload, contractility, and neurohumoral activity. 271,29,30) There are some controversies concerning the effect of acutely increased afterload on systolic time intervals. Wigger noted, using a dog preparation, a slightly decreased ejection time with the increase in aortic pressure. ${ }^{31}$ Harris and co-workers showed that acute pharmacologic vasoconstriction prolonged PEP through reflex stimulation of vagal efferents to the heart. ${ }^{22)}$ On the other hand, it was reported that ejection time was increased and ICT was shortened by constriction of aorta. ${ }^{33)}$ Alture suggested that $\mathrm{Mg}^{++}$increased the affinity of vasopressin for its receptor on blood vessels. ${ }^{34}$ ) In the present hemodynamic study total peripheral resistance index tended to increase, while the changes of systolic time intervals might be affected by a little increase in peripheral arterial resistance, but these intervals could be altered mainly by the depressant action on myocardial contracility. ${ }^{21,22)}$ These findings agreed with other studies. Santurbuny and Farah demonstrated using the heartlung preparations that increase of magnesium concentration in serum diminished the systemic output, ${ }^{35)}$ and another group observed the cardiac output of dog decreased with increase of magnesium concentration. ${ }^{36)}$

Smith and co-workers have noted the development of tachycardia with elevations of plasma magnesium concentration to $5 \mathrm{mEq} / \mathrm{L}$, but bradycardia at higher magnesium concentration. ${ }^{37)}$ Several investigators confirmed that a depressant action on rhythm and conduction and a transient tachycardia at a small elevation of magnesium concentration were explained by the fall of blood pressure. ${ }^{37)-39}$ The fall of blood pressure was explained by decreased cardiac output or vasodilatation produced by magnesium, but in this study heart rate was increased and blood pressure elevated. These observations are consistent with the experiments of Somjen and co-workers, ${ }^{38)}$ and Toda and West showed that $\mathrm{Mg}^{++}$diminished the negative chronotropic effect of vagal stimulation in isolated atria of rabbit. ${ }^{28)}$ The stroke volume follows an inverse linear relationship with heart rate. In this study heart rate increased and cardiac index tended to decrease. Decrease of stroke index may be not only due to the effect of increase of heart rate, but also negative inotropic action of $\mathrm{Mg}^{++}$. 


\section{ACKNOWLEDGEMENTS}

The auther is grateful to Prof. R. Takeda and Prof. E. Murakami for their kind guidances and expresses many thanks to Drs. S. Kawasaki, S. Ishise, T. Funatsu, M. Tsuchiya, N. Takekoshi, and N. Genda.

\section{REFERENCES}

1. Somjen GG, Baskerville EN: Effect of excess magnesium on vagal inhibition and acetylcholine sensitivity of the mammalian heart in situ and in vitro. Nature 217:679, 1968

2. Kasz AM, Repke DI: Clacium-membrane interactions in the myocardium: effects of ouabain, epinephrine and $3^{\prime}, 5^{\prime}$-cyclic adenosine monosphate. Am J Cardiol 31: 193, 1973

3. Uchida E: Contraction and relaxation of vascular smooth muscle and calcium, strontium, barium. Jap Circulat J 39: 193, 1973

4. Anderson TW, Neri LC, Hewitt D, Schreiber G, Marier JR: Magnesium in hear muscle. Lancet 2: 644, 1976

5. Kasz AM: Effects of ischemia on the contractile processes of heart muscle. Am J Cardiol 32: 456,1973

6. Burton EF, Makay JM: The influence of cations on contracture in the superfused ventricle of Helix aspersa. Experientia 26: 151, 1970

7. Hoffman BF, Suckling EE: Effect of several cations on transmembrane potentials of cardiac muscle. Am J Physiol 186: 317, 1956

8. Aoki K, Jazumi K, Kato S, Sato I, Hotta K, Yamashita $\mathrm{K}$ : $\mathrm{Ca}^{++}$binding ability and release of sarcoplasmic reticulum from arterial smooth muscle in spontaneously hypertensive rat. Jap Heart J 17: 352, 1976

9. Bauer FK, Martin HE, Mickey MR: Exchangeable magnesium in hypertension. Proc Soc Exp Biol Med 120: 4661965

10. Weissler AM, Harris WS, Schoenfeld CD: Bedside technics for the evaluation of ventricular function in man. Am J Cardiol 23: 577, 1969

11. Hamilton WF, Moore JW, Kinsman JN, Spurling RG: Further analysis of the injection method and of changes in hemodynamics under physiological and pathological conditions. Am .J Physiol 99: 534, 1932

12. Tsuchiya M: Hemodynamic studies on hypertension. Jap Circulat J 36: 267, 1972

13. Bessingthwaite JB, Reuter $\mathrm{H}$ : Calcium movements and excitation-contraction coupling in cardiac cell. in Electrical Phenomena in the Heart. Academic Press, New York, pp 3533591972

14. Nayler WG, Seabra-Gomes R: Excitation-contraction coupling in cardiac muscle. Prog Cardiovas Res 18: 75,1975

15. Nayer WG, Dunnet J, Sullivan A: Drug-induced changes in the superficially located stores of calcium in heart sarcolemma. Recent advances in studies on cardiac structure and metabolism. University Park Press, Baltimore, pp 53-70, 1976

16. Grossman A, Furchgott RT: Effects of various drugs on calcium exchange in siolated guineapig left auricle. J Pharmacol Exp Therap 145: 162, 1964

17. Nayler WG, Szeto J: Effects of verepamil on contractility, oxygen utilization, and calcium exchangeability in mammarian heart muscle. Cardiovas Res 6: 120, 1972

18. Nayler WG: An effect of ouabain on the superficially located stores of calcium in cardiac muscle cells. J Molec Cardiol 5: 101, 1973

19. Famer JB, Campbell IK: Calcium and magnesium ions. Influence on the response of an isolated artery to sympathetic nerve stimulation, noradrenalin and tyramine. Brit $\mathrm{J}$ Pharmacol Chemotherap 29: 319, 1967

20. Fabiato A, Fabiato F: Contractions induced by a calcium triggerd release of calcium from 
the sarcoplasmic reticulum of single skinned cardiac cells. J Physiol 249: 4691975

21. Garb S: Effects of potassium, ammonium, cecium, strontium, and magnesium on the electrogram and myogram of mammalian hear muscle. J Pharmacol Exper Therap 101: 317,1951

22. Reiter M, Noe J: Die Bedeutung von Calcium, Magnesium, Kalium und Natrium fuer die rhythmische Erregungsbildung im Sinusknoten des Warmblueterherzens. Arch ges Physiol 269: 366, 1959

23. Weister AM, Peeler RG, Roehll WH: Relationship between left ventricular ejection time, stroke volume, and heart rate in normal individuals and patients with cardiovascular disease. Am Heart J 62: 367, 1971

24. Wallase AG, Mitchell JH, Skinner NS, Sarnoff SJ : Duration of the phases of left ventricular systole. Circulat Res 12:611, 1963

25. Weissler AM, Harris WS: Systolic time intervals in heart failure in man. Circulation 37: 149,1968

26. Garrand CL Jr, Weissler AM, Dodge HT: The relationship of alterations in systolic time intervals to ejection fraction in patients with cardiac disease. Circulation 42: 455, 1970

27. Weissler AM, Schoenfeld GD: Effect of digitalis on systolic time interavls in heart failure. Am J Med Sci 259: 4, 1970

28. Toda $\mathrm{N}$, West TC: Interaction between $\mathrm{Na}, \mathrm{Ca}, \mathrm{Mg}$ and vagal stimulation in the $\mathrm{S}-\mathrm{A}$ node of the rabbit. Am J Physiol 212: 424, 1967

29. Shaver JA, Kroesz FW, Leonald JJ, Paley HW: The effect of steady-state increase in systemic arterial pressure on the duration of left ventricular ejection time. J Clin Invest 47: 217,1968

30. Harris WS, Schoenfeld CD, Weissler AM: Effects of adrenergic receptor activations and blockade on the systolic preejection period, heart rate, and arterial pressure in man. J Clin Invest 46: 1704, 1967

31. Wigger GJ, Kasz LN: The specific influence of the accelerator nerves on the duration of ventricular systole. Am J Physiol 33: 49, 1920

32. Harris WS, Weissler AM, Brooks RH: Vagal influences on left ventricular contraction in man. A cause for prolongation of the preejection period. Clin Res 14: 426, 1966

33. Matsuura T, Goodyeer AVN: Effects of a pressure load on left ventricular systolic time intervals. Am J Physiol 224: 80, 1973

34. Altura BM: Influence of magnesium and cystein on vasopressin-induced contractions in various canine blood vessels. Experientia 26: 1089, 1970

35. Stanbury JB, Farah A: Effects of the magnesium ion on the heart and on its responses to digitoxin. J Pharmacol Exper Therap 100: 445, 1950

36. Maxwell GM, Elliot RB, Burnell RH: Effect of hypermagnesemia on general and coronary hemodynamics of the dog. Am J Physiol 208: 158, 1965

37. Smith PK, Winkler AW, Hoff HE: Electrocardiographic changes and concentration of magnesium in serum following intravenous injection of magnesium salts. Am J Physiol 126: 720,1939

38. Somjen G, Hilmy M, Stephen GR: Failure to anesthetize human subjects by intravenous administration of magnesium sulfate. J Pharmacol Exper Therap 154: 652, 1966

39. Engback L: The pharmacological actions of magnesium ions with particular reference to the neuromuscular and the cardiovascular system. Pharmacol Rev 4: 396, 1952 